\title{
The Christian Democratic Youth of Slovakia: Christian Legacy, Post-Socialist Memory and the Present Spirit of Capitalism
}

\author{
MATEJ KARÁSEK* - L'UBICA KOLLÁROVÁ** \\ Department of Ethnology and World Studies, \\ University of SS. Cyril and Methodius in Trnava \\ “matkokarasek@gmail.com, **lubicak@gmail.com
}

\begin{abstract}
The subject of this case study is the youth political organisation Christian Democratic Youth of Slovakia (KDMS). The first parts of this paper are dedicated to history and the structure of organisation. Latter parts discuss the influence of historical memory on creating the collective discourses of KDMS and its civic engagements, ambitions and activities. The purpose of the paper is also to evaluate the role of religion and secularisation in KDMS agenda and also to discuss the ways how the 'christian heritage' becames the source for arguments in political debates and opossitely how the christianity could be interpreted in the light of conservative and right oriented socio-economic and political worldview.
\end{abstract}

KEY WORDS: Christian Democratic Youth of Slovakia, memory, religion, secularisation, youth activism

\section{Introduction}

This paper is an ethnographic case study of youth activism in Slovakia focused on the youth political and Christian-based movement, the Christian Democratic Youth of Slovakia (KDMS). It conforms to the Myplace project, whose fundamental aim is to capture and interpret the meanings young people attach to the social world, and presents a qualitative ethnographic study focused on young people's civic engagement and political activity. 
Before the early 1990s, no scientific tracking of youth activism in Slovakia (the former Czechoslovakia) was conducted. This was rooted in the political situation before 1989 when the communist regime and its propaganda drove the country. At that time, youth was surveyed as a product of successful political socialisation, ideologically based on Marxist-Leninist concepts, on a platform of official local and national youth organisations (e.g. Socialistický zväz mládeže, Československý zväz mládeže, see MACHÁČEK 1993). Other forms of organisation were banned and considered anti-state or anti-regime. Regarding ideological self-expression, the limited freedom of youth in politics generally caused virtually all youth activities to take on a political character (KOVACHEVA 2002). A characteristic feature of the Eastern bloc at that time was the lack of academic interest in youth activism as such. During the 1960s and 1970s, new approaches in social studies, focusing on youth, were only in their infancy ${ }^{1}$ and followed the regime's needs. The situation in the academic field changed during the 1990s, after the Velvet Revolution, especially in the field of sociology, using quantitative research methods. Nonetheless, systematic qualitative research of youth has not yet been carried out. Thus this case study, focused on youth political activism, partially fills the gap in qualitative analysis in the field of youth studies.

Politically-based youth organisations or movements have a long tradition in Slovakia. Throughout history, each regime has generated politically active youth, e.g. the Hlinka Guard (1939-1945) and the Socialist Association of Youth (SZM) (ŠTEFANČÍK 2010:51). The Christian Democratic Youth of Slovakia (KDMS) is considered the oldest youth political movement in Slovakia. Established in the early 1990s, after the Velvet Revolution, it has been registered as a civic association since then, as the youth branch of one of the first post-revolution parliamentary parties, the KDH (Christian Democrats of Slovakia). Its main goal is the propagation of Christian, civic, and national principles as well as active participation in social (public) and political life by spreading KDMS's four core values (4S): 'Freedom, Justice, Solidarity, Subsidiarity' ('Sloboda, Spravodlivost', Solidarita, Subsidiarita'). ${ }^{2}$ Currently KDMS is the largest organisation of politically organised youth that openly subscribes to a Christian worldview and political aims. It has a wide base across the country and participates in and organises events that fit within the scope of its goals. Note that Christian tradition, values, and politics should be understood in this context as predominantly Roman Catholic.

See works of Jiří Suchý: 1969, 1972,1979, 1985, 1989, and the later generation of scientists such as Macháček 1976, 1980, Fogaš 1980, Migaš 1984, Zozulák 1984, Dul'a 1987.

2 See http://www.kdms.sk/node/223, accessed 19 November 2013

DOI: 10.1515/eas-2015-0008 C University of SS. Cyril and Methodius in Trnava. All rights reserved. 
Therefore, the movement merges general political ideas, individual political ambitions and Christian values, adhering to Christian ideals while being politically active. Thus, there is a need to define the secularisation of youth political organisations and secularism as such. The first research question to be posed is whether KDMS is more a religious or politically based organisation. Because KDMS is a right-oriented, conservative Catholic youth movement, its political socialisation is represented by different events: workshops, classes, and team-building activities; a focus on preferred political aims and positions (such as strengthening political transparency, opposition to political corruption, communism and socialism; support for the EU, an open civic society, and motivating young people to participate in public affairs). It also advocates for certain policies aligned with their Christian values, such as promoting the traditional definition of the family and opposing abortion, euthanasia and registered homosexual partnerships. The religiosity of members is not a condition of membership but is an expected priority. Generally, however, this description is not only about Christian principles, but also about the presence of a hybrid phenomenon - political Catholicism. The second research question is related to intergenerational transmission and memory, about how collective memory shapes history, and how our surroundings make us aware of the past through particular icons and symbols as tools of activism. Basically, the general aim of the research was to understand youth activism through an examination of KDMS's activities, historical discourse and intergenerational transmission.

\section{A short history of the organisation}

As noted above, Christian Democratic Youth of Slovakia (hereafter referred to by its Slovak acronym KDMS) was established in the 1990s as the youth branch of the parliamentary party Christian Democratic Movement (KDH). In those post-revolution times, almost every parliamenty party had a youth branch for young people who were interested in social and political life and wanted to participate in politics. However, KDMS was the only movement that officially declared Christianity as one of the main principles of its organisation. Despite the totalitarian regime, Slovakia remained a religious country which also drove the popularity of Christian principles in politics after the Velvet Revolution. ${ }^{3}$ Since the beginning, KDMS has been the largest youth organisation supported by its parent party. According to one respondent, KDMS began with around 20,000 members, four offices and about 10 cars for official use. In July 1994, at the European

According to the 2011 census, 67 per cent of the Slovak population identify as catholic. (http://portal.statistics.sk/showdoc.do?docid=44035), accessed 19 November 2013. 
Committee of Youth in Graz, Austria, KDMS became an official member of Christiandemocratic and folk youth parties in Europe (ŠTEFANČÍK 2010:56). The rise in youth groups which occurred after the revolution lasted about 10 years until the first generation of members outgrew the youth organisationsand the number of members began to decrease. The other factor which had a direct impact on the group's membership was the situation in its parent party, the KDH. The departure of Vladimír Palko and a few other KDH members in 2008 caused the leadership of KDMS to depart as well. At the time, there was a significant decrease of KDMS membership, which reached its lowest number, 200 members. The new leadership began the era of KDMS which continues to this day. The group's membership numbers have recently improved, reaching 400 .

One of the most important of KDMS activities is motivating young people to participate in European politics and social issues via cooperation projects with the European Parliament and through active partnerships with foreign youth organisations. In recent years, these aims have been met by negotiating a partnership with German, Polish, Czech and Hungarian youth organisations. Recently, KDMS has been running a very popular campaign called 'A young trainee in the European parliament' ${ }^{4}$ supported by the European Commission and a Slovak conservative Member of European Parliament Anna Záborská. ${ }^{5}$

The connection between youth organisations and high-ranked politicians in Slovakia is embodied in present politicians, activists and media figures who were formerly members of KDMS: Peter Tóth (former journalist of the daily newspaper SME, and later head of the secret service e - SIS), Members of Parliament Peter Muránsky and Mária Majdová, Ján Mojžiš (head of the National Security Authority), Jana Tutková (a pro-life activist), Boris Ažaltovič (spokesperson for the Interior Ministry), and Martin Krajčovič (spokesperson for the Transport Ministry) (ŠTEFANČÍK 2010:56).

KDMS has organised many events, workshops, seminars, and other activities on its own or with the support of its parent party (Ibid). A few of these activities have become a tradition. One of the most important events of this kind is the annual climb up Mt. Dumbier (the highest peak of the Low Tatras) which began in 1991 as a weekend gathering of Christian youth in Slovakia. Apart from its other activities, KDMS co-organises and

https://www.facebook.com/mladystazista, accessed 21 November 2013.

Anna Záborská is the daughter of former KDH leader Anton Neuwirth (http://www.zaborska.sk/), accessed 21 November 2013. 
supports the pre-electoral campaigns of the $\mathrm{KDH}$, even though it declares itself an independent group.

In general, the members of KDMS are young Catholics, aged between 15 and 30 years. Membership is based on good relations, recommendations and a will to participate in a social and political life which involves meeting new people who share similar ideas and values. The organisation's hierarchical structure is based on a two-tier, national and local county-level-based chairmanship (e.g. Chair of Bratislava county, chair of Banska Bystrica county, etc.). Leaders are elected for two-year terms by the organisation's board. It can elect anyone with the respect and authority of its members.

Members can communicate with each other via the official website (www.kdms.sk) and Facebook. Both sites report all upcoming events and publish reports on past activities. The websites also contain a photo gallery and a registration form, as membership is required to gain full access to information about activities.

KDMS activities aspire to form 'capable, confident young people who can take responsibility for themselves, their family, community, citizens and state'. Its aim is to enable young people to participate actively in public life, to promote their professional development, establish Christian values and provide a decent education for such an agenda on the national, European and world level. ${ }^{6}$

\section{Methodology}

In line with the Myplace agreement on methodology relating to the WP7 ethnographic studies, this case study is based on qualitative research data analysis. The uniqueness of this approach lies in the lack of qualitatitive data of this kind. In fact, quantitative data analyses in the field of youth studies has been predominant until recently. Using ethnography as a method helps us describe the surveyed group from inside. The ethnographic character of the research predicts a qualitative approach based on participant observation, fieldnotes, and recorded semi-structured interviews as the main data gathering methods. Participant observation enabled the researchers to grasp the activities of KDMS in greater detail by taking part in official gatherings and events. Researchers also took part anonymously in a few demonstrations (e.g., the demonstration in favour of the traditional family which took place on 11 September 2012, the march against registered partnerships in Bratislava of August 2012 and the Gay pride march in Bratislava on 21 September 2013). Initial contact

6 For more information see http://www.kdms.sk/node/21, accessed 21 November 2013. 
with KDMS members was made via the KDMS web pages, through which researchers registered in order to attend their first official meeting. Over the duration of a yearthey officially joined gatherings, meetings and other KDMS activities of which the most important were the annual gathering focused on young leaders in Donovaly and the meeting of regional KDMS leaders in Nitra.

The first impressions formed in the field were of a friendly and open environment. The researchers were officially introduced by the authorities, who asked the members to talk to them. Most of the interviews were conducted separately from the gatherings. The research strategy was to make contacts while participating. Sessions attended were observed and notes about KDMS activities, topics discussed and workshops were jotted down in field diaries.

As mentioned above, interviews were conducted on a one-to-one basis. The length of each interview varied between a minimum of 50 minutes and a maximum of 170 minutes. A total of 20 semi-structured interviews, around 30.8 hours of audio material, was recorded. Most of the interviews took place between October and December 2012. Due to difficulties with the time schedule, some interviews were postponed at the request of the respondents. Thus, interviews continued into the first quarter of 2013. To summarise, all the interviews were transcribed and a total amount of raw material amounts to more than 400 pages while the visual databank contains 119 pictures and an unprocessed video taken in the field.

Researchers did not encounter any significant ethical issues or dilemmas. Each respondent was informed of the MYPLACE research ethics statement. A consent form and participation sheet guaranteeing respondents' anonymity was signed by both researcher and participant. Respondents were also shown a declaration that no information would be abused, as stated in the Myplace Ethics Framework. Anonymising the ethnographic data required the removal of anything that would identify interviewees and so respondents were identified only by a single pseudonym (Anna, Barbora, Boris, Cyril etc.). Regarding secondary sources, a content analysis was carried out of the KDMS web pages, Facebook and other online sources, and of visual and video material related to the case study. Following the research questions, every interview was analysed within the survey structure and aims. The case study resulted in the mosaic of outcomes described below. 


\section{Key findings}

\section{The KDMS case study}

Though the name KDMS implies that it is an organisation for religious young activists, observation of their meetings and other events indicates that the goals of these activist efforts are more political and social in character than religious. The research shows that Christianity is conceived of as a justification for enacting into law the political and social visions of young activists. The interviews with the activists and monitoring performed among them show a high degree of secularisation of Christianity and the values identified with Christianity by respondents. From the interviews and the discussions overheard between KDMS members, the researchers observed that political issues are crucial and Christianity itself (literally Christian values) is most frequently mentioned purely as a political or social argument against the political opposition, the left wing (which is discursively connected with Socialism or even Communism), and social Liberalism ${ }^{7}$.

One 'anomaly' encountered in this research could be mentioned here as an indicator of the secular approach among group members. To be specific, the 'anomaly' is represented by a twenty-year-old informant who ceased to identify himself with Christianity after being active in KDMS for two years and impacted by life changes. Though his divergence from Christianity was followed by the dilemma of whether or not to leave KDMS, the informant eventually decided to remain with the organisation. The respondent explained:

"Christian principles and many values are close to mine. Though I'm not a practicing Christian in terms of going to church or Mass, etc., as an individual I'm conservative. Many of those principles and traditions are close to me. I was a Christian, but I've been through certain changes in life just like many other people. I do not condemn Christianity but I've moved to different ideas. //...// Their environment is so very tolerant, and that is also why I like KDMS, they do not request it directly and as we strive to arrive at policy, Christianity is emphasised in terms of values and traditions rather than active practice. Of course that is one side, but simply going to church, being a Christian, it is not necessary to be with KDMS. //..//We, as an organisation, operate on Christian principles, but the organisation does not focus on this active side. It is included-for example, Mass forms a

\footnotetext{
The rejection of 'liberal' approaches (such as legalised abortion, the decriminalisation of marijuana or registered homosexual partnerships) that forms a significant part of the organisation's agenda will be addressed later in this paper.
} 
part of some larger events, but it is a minimum considering KDMS's overall orientation and activities.” (Ján)

The secularism of the KDMS youth has also been impacted by a memory discursive heritage reflecting the past totalitarian regime. As the then-State suppressed Christianity, in Socialist times Christianity became a symbol of anti-Communist protest and the bestknown personalities of Slovak dissent expressed the need for political and social change from the position of oppressed Christian identification.

One such personality is Ján Čarnogurský, a controversial former Slovak politician, who contributed to the establishment of KDH as a Parliamentary party. According to some respondents, the idea of founding the youth organisation, KDMS, was also his. Some informants revere Ján Čarnogurský as an anti-Communist dissident and their political idol ${ }^{8}$.

Young Christian activists who have not experienced Socialism or do not remember it truly seem heirs to a memory discourse that conflates anti-Communist activism, civil rights principles and democracy (and even the market economy system) with Christian activism:

"Civil principle is based on how Christian democracy was formed in Slovakia, i.e., during the fall of Communism, and Christian dissidents were those sitting in prisons. Ján Čarnogurský, František Mikloško, the Candle Demonstration, etc. It was the underground Christian church that brought human rights and liberties in the West, e.g., the freedom to travel, the right of assembly, free speech - and this is the background of civil principle. That means that a citizen is a master within a state. Neither politician, nor mafia or other hierarchy but all those human liberties - petitions, referenda; this is civil principle." (Fedor)

It seems that the 'collective memory' of young Christian activists includes discourse that unites religious, civil and economic liberties and puts them in a kind of automatic 
polarity with Communism as a homogenous and clear symbol of the suppression of those liberties.

In spite of the respondents ' very definite opinions about Socialism, they demonstrated an extremely limited knowledge of Communism and its historical background. For example, one thirty-year-old respondent said that his historical-political anti-heroes were 'Stalin, Hitler, Marx, and all those who oppressed freedom' (Ivan).

In terms of a common background of Czechoslovak Socialist, day-to-day reality, KDMS members make mistakes that surely would not be made by any senior. While monitoring the group, for example, researchers observed a situation in which a young member of KDMS spoke about a type of car that used to be a police car in Socialist times. Both the police cars and the state police were designated as VB (Verejná Bezpečnost' or public security). However, the activist designated the car as ŠTB (Štátna Tajná Polícia State Security Agency), a feared security agency.

The car and Russia as Socialist elements in historical memory are connected with one KDMS activity which was less noted by the media. They decided to bring an old Russian car - a Žiguli - to the entrance of the Government Office. The car was a symbolic 'gift' for the leftist Prime Minister, Róbert Fico, who was visiting Russia that time. Thus:

"We delivered a Žigulák to Fico, as it was the November 1989 Anniversary, i.e., the anniversary of freedom, and he went to Moscow to commemorate the victims of Communism. We gave the Žigulák to him to tell him not to come back, as he did not notice it was November, 1989." (Fedor)

Just how intergenerational transmission of 'memory traces' of Socialist totalitarianism takes place is unclear. Similarly unclear are the methods of transmission of discourse equating anti-Communism with Christianity (after all, a Catholic Communist is not an uncommon phenomenon in Slovakia, with the former Slovak President, for example, proving this point). While differences of opinion between parents and their children on political topics are in some cases significant, all the respondents were raised in the Christian tradition. In addition, the respondents' parents were active participants in $\mathrm{KDH}$, either in Parliament or at community level. These respondents have a clear 'social background', based on their relatives' experience in $\mathrm{KDH}$, that gives them access to top positions in KDMS structures.

Based on the abovementioned, it can be argued that this background also includes the direct transmission of KDH's political discourse and specific contents of historical memory that may be mobilised as sources of KDH's political power. The secular aspect of this specific type of intergenerational relationship is that, along with the transmission of 
religious outlook, political outlook can be transmitted from politically active parents, i.e., historical memory and even social background can result in the enhanced social status of these individuals in the youth organisation. If the information received through informal discussions with two respondents is valid (taking into account the informal character and intimacy of the conversations where no information was provided by the researchers, nor any cited), then $\mathrm{KDH}$ tries to maintain control over, or at least tries to indirectly influence, the selection of KDMS leaders. Hypothetically, promoting the children of KDH members could be one way to keep control and influence over the youth organisation's direction but the researchers did not manage to either prove or disprove this hypothesis.

The statement of one respondent, a son of former KDH MPs, provides strong evidence of transmission of discourse connecting Christianity with the fight against Communism, whereas, in fact, religion has a political and secular position. It also provides evidence of the potential sources of the social background of KDMS activists. He stated:

"I've been a Christian Democrat since my childhood. In Communist times, during my secondary school studies, my mother was denounced as a collaborator with Imperialist powers. This meant that her sisters were not allowed to study human science studies, but had to study technical studies, because they attended church. I was raised withthat background all my life. My father was a KDH MP for eight years, so I can remember 'Mečiarism', I remember Dzurinda, I remember Figel' as a young man who came to spend the night at our house and I had to give up my room to him. Figel', Hrušovský, Dzurinda, they all slept there in my room. My background was naturally Christian Democrat; since the beginning, I have been a Christian Democrat." (Fedor)

However those former members of KDMS who not only commemorate November 1989 but remember it in person can also perceive the relationship between Christianity and Socialism from other perspectives. It is true that Christianity limited by Socialist power was understood by both 'Communists' and anti-Communists as being in opposition to everything 'Communist'. On the other hand, it is necessary to state that after the revolution, approval of the liberation of the political environment and religious freedom (notably demonstrated after being kept in secret for years) could be expressed through affiliation with the KDH party or its youth organisation, including its political and economic visions. Thus, at that time, the reasons for enrolling in these political parties could have had a more pragmatic motivation compared to present-day. Whereas in urban centres, Christian identification was, after the revolution, connected with a secular policy, economic, and social vision, in the rural periphery, entry to KDMS could be a more complex and very specific reflection of transmission difficulties. As discourse on Christian ideology's incompatibility with every aspect of Communism actually existed on the 'Communist' side as well, entry to the organisation could have been motivated primarily by religious rather than political 
sentiment. This possibility is supported by a respondent who established a KDMS chapter in his village after the revolution. He said:

„I was solving the youth situation in Dolná Krupá, as the clubs there were previously unionist (Union of Socialist Youth) and there was a kind of gap after the revolution, everything was locked down. One group was set up around the church, with a choir and singing activities, and it was a problem to get people there, those who did not want to be directly close to the Church and thus there was a gap for those who were searching but did not have the courage to go to the Church as such, and there was the idea to start up a kind of club, of course under some idea, so that it had a certain Christian background. This was the way, but as the mayor was a former Communist, the situation was that he was obstructing any such activities. When we wanted to establish something - [he would ask] who are you, who do you think you are, you can't come in just like that. And so I had an idea, a reasonable one. I set out on a journey to Žabotova street in Bratislava and requested confirmation that we want to set up a kind of youth club affiliated with KDH; they sent me from one office to another and another and to Carnogursky's office. I had to repeat myselft to five people, why ... and what for... what intentions? The result was that I came back home with an approval for the Christian Democrat Youth. At this point the idea originated that something like that would probably be necessary ....to create some space. We called it the Andromeda club, and as such came to the mayor. KDMS was thus established in Dolná Krupá. We received a room in an old cinema and it started well. Those beginnings were euphoric, a lot of videos, a few people had a video player at home, each brought some videos, we watched films; it was for the village, for the young who had no access to things, so they were simply searching for it. We had a film covering these Christian issues but it always broke out into watching action thrillers. But this in a way covered the gap which had arisen; all those previous activities (unionist activities) were stopped totally due to the revolution. Even firemen were almost afraid that their activities were related to the previous regime! It was a rupture, total gap. Then, people said, we cannot remain in isolation, something must be done. And when I came back from the seminar, they were active, playing instruments during masses, going out on bicycles with children. I/.../II experienced a lot. For sure, this formed me, this impacted me strongly, I like to go back to that time. I can recall those years, the awesome euphoria that a huge change was coming and we were a part of it. We did not know what, where, how, it was huge chaos and we were searching for ourselves in all that." (Karol)

After the early Post-Socialist euphoria, the number of KDMS members and their motivation for enrolling changed. In the early 1990s, KDMS registered 10,000 members; today there are 400 . 
The older and long-term KDMS members have described it as a kind of generational change, and they admit that in recent times some people have entered the KDMS for personal gain, though they usually claim that these people are a minority in KDMS. Membership of the KDMS may bring certain benefits and future opportunities:

„//...//a lot of those in KDMS are interconnected. E.g. Radoslav Procházka, a KDH MP who came from KDMS, Jana Žitnaňská, not these days, but she was at the birth of KDMS, MP Muranský from Bystrica, a former KDMS member. Of course it is interconnected. Our former Head, Martin, is current spokesman for the Speaker of the Parliament, previously a spokesman for the Minister of Transport (a Ministry previously led by KDH). There are a lot of people who were in KDH's head office or active in organisations which are somehow connected, although not necessarily directly, to KDH. A lot of our people are MP's assistants, so there is a clear - there is interconnection. " (Fedor)

The KDH usually leaves one place on the ballot paper for a KDMS member. Though this place is almost unelectable considering KDH's preferential voting and its percentage representation in the Parliament (in the last two election rounds, the place given to a KDMS member on the ballot paper was at position 25 and 50 respectively, which means the candidate is basically unelectable) respondents believed that KDMS membership could be a way into the Parliament; and one activist did manage to get to Parliament in this way.

Informants interpret this KDH gesture as motivation for politically committed and active members of KDH (Barbora). Another informant finds that being in KDMS has potential benefits for his business activities:

„I'm constantly learning something new, as some politicians always come, e.g. now it's MP Fronc, I learn something new, get some new information that I can use for my benefit or I keep it for myself. In fact, I'm in. " (Ivan)

Activism in KDMS can also 'bear fruit' in the form of a post as an assistant to an MP, or as a spokesperson in any institution controlled by the KDH which, in terms of both money and career, can be an enviable job for a student, considering how many students must take dead-end jobs in hypermarkets to make ends meet.

The observations of and interviews with some respondents indicate that KDMS can be a kind of 'training ground' on which young activists learn to play high politics. Several activists admit that there are antagonistic platforms within KDMS; certain coalitions and oppositions can be observed. A fight for power reminiscent of politics can also be observed in KDMS. On oneoccasion, the annual trek to the Low Tatras' highest mountain was accompanied by an event when a certain group of KDMS members attempted to impugn the honesty of a newly appointed Head of the organisation by distributing hoodies which 
implicitly discredited him. The hoodies depicted a tomato (a reference to his surname) reaching out for a wad of cash. 'I don't like tomatoes!' was the caption below the picture. The activist group handed out these hoodies on the peak of the mountain where it was cold, and many activists who were not prepared for such weather took them regardless of their opinion about the new Head of the organisation. According to some respondents (Boris; Barbora) such a costly purchase of hoodies could not have been organised by KDMS student activists, and had to have been organised by someone from the Parliamentary KDH, for whom this person was not the most convenient choice.

These political tendencies and use of political background in the KDMS is also confirmed by respondents:

„What connections ... who receives what, in fact, it is a small version of high politics. Political machinations, gossiping. Various techniques and influencing of the public. Whether it is correct in a youth organisation, to me it seems comic, little children playing at adult politics. “(Ján)

The parliamentary arm of the KDH thus influences the worldview of young Christian activists. It also tries to influence the activities and direction of the youth organisation, despite KDMS's bylaws which declare the independence of the organisation. KDMS's dependence on KDH is obviously proved by the fact that 'each KDH fragmentation means a KDMS fragmentation' (Ján). Such fragmentation was last demonstrated when several MPs left KDH's MPs' club and set up a new political party. This event preceded a group of KDMS members leaving the organisation and founding a new youth organisation which then declared support for the new political party.

Similarly, several respondents admitted that should KDH not be voted to Parliament, KDMS would lose ground. At this point, the secular character of the organisation can be observed once again.

Though activists who have been with the organisation for longer speak about a new generation with a few individuals motivated by personal gain, many activists speak about the more idealistic motives that led them to join KDMS. The initial reasons for joining KDMS are more often driven by an abstract notion of 'bonding together' with people who have a similar background and values to help society:

"I would like to do something beneficial for society, dedicate my leisure time to helping society, and why Christian? I'm assuming that the people with whom I work for will at least have the same value background and values index. "(Žaneta) 
However this 'similar background of values' seems, at least among ordinary members, a proxy for a 'target group' where one can gain social contacts and friendships. So, where some respondents are concerned, it would seem that they are primarily motivated by seeking others with a similar worldview rather than by effecting change in Slovak society. That is why the fact that many KDMS members are brothers and sisters is not necessarily or solely explained by an intergenerational transmission of world outlook or a collective historical memory. This is also proved by an interview with two sisters (Klaudia; Michaela), where the elder sister states that becoming acquainted with people with similar opinions was the reason for her entry, while the younger one entered KDMS under the impulse of her elder sister, who told her that 'it is good in KDMS and there are a lot of interesting people' (Klaudia). In this way it is enough if an informant is Christian and identifies with at least one point of KDMS' or KDH's agenda (often the one point of agreement is the abolition of abortion). At the risk of generalising to a degree, it could even be claimed that the motives of political commitment are more often attributable to highly positioned KDMS members and a social motive (socialising with a group of people with shared values and opinions) prevails among ordinary members having no significant position. A grasp of political trends in the Slovak political environment and the parent organisation KDH itself reflects proportionally on one's position within the organisation. While more committed members have a good overview of such trends, 'social' members often claim that they are unable to express their opinion on politics-related issues.

KDMS activities as such, however, are more reminiscent of a hobby club than an organisation with a marked capacity for political mobilisation. Except for bringing the aforementioned Russian car to the Slovak Prime Minister's office and symbolically burying justice as a reaction to the state of Slovak justice, the organisation has not engaged in significant political activity. Even support for KDH's most recent election campaign, where young activists' participation was expected, was mainly orchestrated by KDH. The parliamentary party created the so-called 'white team', which was to be an election campaign working group. Although the majority of the 'white team' were from KDMS, control and leadership was taken over by members of the parliamentary party. Like the respondents, the researchers were unable to determine why $\mathrm{KDH}$ established a new organisation for the election campaign (KDMS usually took on this task), but based on the former's indications, it can be assumed at the very least that the 'white team' was established because KDH representatives' mistrusted KDMS leaders, and particularly their ability to mobilise members of the organisation to support the campaign.

The activities most often organised by KDMS and most often mentioned by the respondents are social rather than political activities. In their accounts, respondents most 
frequently mentioned KDMS activities such as the trek to Mt. Dumbier (the highest peak of the Low Tatras) or KDMS football tournaments in which several KDH MPs participate.

The KDH MPs also lead training workshops on topics of interest to young activists, for example, a lecture on the Slovak university system led by the former Minister of Education.

The opinions of KDMS members about its leaders can be divided according to their preferred activities within the organisation. For example, one group of members likes it when leaders provide a large number of entertainment or training activities, while a second group of respondents would prefer to focus on the political initiatives of KDMS.

In connection with leadership, again it is possible to observe a battle between the socially and politically oriented members. One of the highly positioned members revealed, in an informal discussion with researchers, that when appointing a leader, KDMS members often vote for the person who pays for a drink and creates a good atmosphere rather than the person who is well informed about political issues and has a vision for the future direction of the organisation. A few respondents said that this deep division among members came to a head during the last election.

Reading between the lines, it could be argued that the last election represented a choice between KDMS's future as a political organisation or its evolution into, literally, a 'Hobby club'. Another respondent said that the election of the present head of the organisation forced the organisation's orientation back to the political mobilisation of youth, conceiving new projects and re-establishing and strenghtening KDMS' position on the platform of European youth conservative movements. Consequently, she added a hypothetical candidate who preferred social activities and camaraderie between members, might not get major political support, mainly because his only followers would be newcomers without experience (Barbora).

So far, aspects of historical memory, related explicitly with the socialist reality of the past, and its influence on the secular character of Christian activism in KDMS has been described. However, the discourse that tracks Christian activism earlier in Slovak history is also worthy of mention. These reflections will allow a consideration about whether the respondents rejected Communism rather than Slovak clergy-Nazism during World War II, as represented by the iconic leader Tiso, who was president and Catholic priest at the same time. The suspicion that KDMS members would prove tolerant of the clergy-Nazism of the past was based not only on the assumption that facism in Slovakia was 'Christian', but also on the fact that one of the former fathers of Christian activism, in Slovakia, the abovementioned Ján Čarnogusrký who is the political idol of many KDMS members, is known for his benevolent and apologetic approach to Slovakia's Nazi history. Suprisingly, 
during the course of this research, it was impossible to find any first Slovak state politician connected to Christian activism and this historical paradigm. ${ }^{9}$ Still, it is very interesting to follow the historical path of 'Christian political activism' in Slovakia with which one can identify. For instance, Herbert Butterfield suggests that each person's mind holds a jumble of images and stories that constitute one's memory of historical events. The past to which Butterfield refers is both historical and personal. Its scenes and experiences antedate one's own life, but what onereads and hears repeated about it, makes it part of one's memories, too (LOWENTHAL 2011:186).

This fact may be demonstrated by the following two quotes:

"As far back as the Great Moravian times, King Pribina..., through his pro-Christian politics, spread Christianity all over the kingdom. Hlinka ${ }^{10}$, Rázus, Šafárik, Bernolák ${ }^{11} \ldots$ In Slovak history, I think, it is hard to separate religion and politics, as they are connected. Both the Catholic and Protestant clergy were involved in politics for a very long time as people with a moral side to them which was not automatically present in politics and everyday life ... Particularly, I sympathise with those who fought against communism, such as Lech Walesa in Poland, who took a stand against ... the communist world. Those people like him, who were able to rebel against the regime, were heroes, dissidents, Catholic priests dying in Gulags. Those people are the right political leaders for me. Thank God we do not need them anymore." (Eduard)

"Christian political activism in Slovakia has always had a place there, it does not matter in which sector, i.e., education or health, and the people who started this were Christians. Sometimes it was a clergyman or the Church in general who, literally, overwhelmed the whole world. Štúr ${ }^{12}$, and all his followers, were Christians, Catholics.” (Ivan)

$9 \quad$ One respondent, located Christian-based political activism also in this era of Slovak History. However, he also said that this example was not worthy of concern because it denied the general rules of democracy.

10 Andrej Hlinka was a Catholic priest and Slovak nationalist who enforced Slovak autonomy during the first Czechoslovak Republic. Andrej Hlinka is also discursively related to the Nazi government (and this government often referred to him); however, he died before the establishment of the first Slovak state during World War II.

11 At this point, the respondent listed the national and historical leaders, poets and persons who, for the first time, codified a written version of the Slovak language in the 19th century.

12 L'udovít Štúr (1815 - 1856) was a Slovak Protestant cleric, the best-known historical personality, and the codifier of the written Slovak language, which has become the basis of the present language standard. 
Despite the fact that many Slovak historical leaders were Protestant, this is a good point at which to state no Protestant KDMS members were interviewed during the course of this study. Also, the research carried out confirms that the Catholic respondents of KDMS 'remember' all historical personalities only as Catholic.

The respondent cited above (Ivan) continued, 'Ludovít Štúr is an icon of the Slovak awakening. I identify myself as Slovak, and I am glad that we are not a part of the AustroHungarian Empire or the former Czechoslovakia any more'. When asked if he knew that L'. Štúr was not Catholic but Protestant, he reacted: " [L'. Štúr] Wasn't he? I know he was. I do not mind. Not all good people are Catholics" (Ivan).

One might assume that strong anti-left tendencies are associated with the extreme and nationalistic right; however, such an ssumption was not borne out in any of the interviews conducted. Activists explained the 'National principle' alongside the 'Christian principle', embedded in the legislative background of the organisation, in terms of national pride, and that a distance was kept from nationalist policy. KDMS members were also asked which youth organisation they did not ever want to cooperate with, and many mentioned the neoNazi organisation Slovenská pospolitost', which openly reveres the Slovak Fascist state of World War II, and which is generally known for its racist rhetoric.

Although KDMS is a Christian organisation, there was no indication, from the interviews conducted, that it demonstrated anti-Islamic beliefs. This point is supported by the responses to the question of whether caricatures of the Prophet Mohammed were in keeping with European democratic values. The overwhelming majority of respondents said that caricature in general is part of freedom of expression; however, at the same time, they argued that it was important to respect other religions, as a mark of basic 'decency' which should not have to be enshrined in law. It was unexpected to come across such moderate views about Islam, as in the case of one respondent who wore a cleric-sized cross around the neck as a visible sign of Christian activism. A student of Catholic catechism, visibly the least secular in word and action of all KDMS members interviewed, said the following about Islam:

"[Islam] was established as a peaceful religion. One might say it is a religion similar to Judaism and Christianity, worshiping God the Father and the Old Testament. These are the basic roots which are the same. The problem lies in the interpretation of Jihad ('to struggle in the way of Allah') and Islamist terrorist movements which is the present danger. If God is love, as we Christian says, then He does not want it this way. The problem is that people rise and defend hatred. Actually, ordinary Muslims are peaceful, living next to Christians in harmony in many states around the world. Referring to one documentary where 
Christian and Muslim families living next to each other had a good relationship, my question is, how huge an impact does hatred have?" (Cyril)

A member's position and involvement in the organisation correlates with the member's political loyalty and the 'correctness' of his or her answers. Respondents in higher positions within the organisational hierarchy are more skilled in answering interview questions in a proper and very politically correct way, with an emphasis on rhetorical style. In contrast, less skilled, younger, and lower-positioned members often betray a latent sympathy with radical thoughts and solutions. It is hard to say whether the behaviour of senior KDMS members is a part of the discourse or just better communication skills, as the researchers did not notice any behavioural dissonance when talking on and off the record ${ }^{13}$.

Even though minimal indicators of radical sentiment were noted several times on the individual level in both older and younger activists, these radical statements most often addressed the Roma minority as the fundamental issue in Slovakia:

"It might seems racist, but I see Roma people as a long-term issue in Slovakia. As a community, they cannot help themselves and it has a negative impact on the whole governmental system and there is a need to solve it somehow...!" (Pavol)

An even more radical statement was noted late one night during a KDMS weekend session, when, after a couple of drinks, a young member (around 18 years old) addressed a few sharp and provocative words to Jews and homosexuals. By the end of the evening, he and a colleague were singing a fascist song from the time of the Nazi-Slovak state ${ }^{14}$. Another 20-year-old respondent, a fan of Nicóla Machiavelli, said openly during the interview, "Hang all gays by the balls" (Ladislav). To summarise, these few examples were noted as the only cases of radical or intolerant speech during the research. It seems that these examples are more the individual statements of youngs people fighting with selfdetermination than the collective discourse of the KDMS. subjective feeling was was that they saw the interviewing process as a challenge, a training exercise in how to communicate with the media or other questioners.

14 The lyrics of the song are related to Nazi- Slovak History during World Waw II and refer to the Interior Ministry as well as to a high commander of Hlinka's Guards, which were the Slovak equivalent of Hitler's SS, to the 'Jewish question', and to Slovak self-determination: "Zo Žiliny ide vlak/ a v ňom sedí Šaňo Mach / všetci Židia utekajú, lebo majú strach. /Rež a rúbaj do krve/ nebude to poprvé/ dokial' Slovák na Slovensku pánom nebude." 
Furthermore, it also seems that KDH former political leader Ján Čarnogurský is for many KDMS members worth following only as a historical symbol of anti-communism, rather than for his controversial opinions. The aspect of his personality cult which defends the Nazi Slovak state during World War II does not impress KDMS activists at all. By stereotyping the concept that East equals communism in the historical memory of proEuropean activists, Ján Čarnogurský's recently documented pro-Russian world-view and his defence of the Warsaw treaty army in Czechoslovakia in 1968 were forgotten. Paradoxically, thirty years ago the same Ján Čarnogurský fought against the regime and occupation and this activism brought him a certain allure in the new economic, social and political conditions after the Velvet Revolution. Thus, he was able to establish KDH and its youth branch, KDMS. In the following discussion, the controversy of historical memory will show how easily an idol can be transformed into a static object, because the faces on busts and sculptures never fade away.

\section{Discussion}

To clarify the discussion about political Catholicism in Slovakia, an understanding of 'secularisation' or 'secularism' is required, together with an appreciation about whether or not either of these notions provides an analytical framework through which the research data can be grasped theoretically.

There are several contradictory definitions of these terms. The first is the definition of secularisation as a turning of religious organisations to worldly concerns (FOX 2005:292) and everyday issues. The Catholic Church views secularisation this way, as do others.

From the researchers' point of view, this perspective is comfortable in many ways. On the other hand, it may be too simplistic since it views religion as a system isolated from other aspects of society and ignores its potential to become a Maussian 'total social fact'. This way of thinking about secularisation triggers the suspicion that it is the result of inconsistent work with reference to the classical sociology of religion (DURKHEIM 2002), which, in spite of the strength of its arguments, frequently relegated religion to an isolated compartment of academic and social constructs.

The process of secularisation in the sense of a turning of religion towards the world thus does not need to have a basis in social changes related to modernity, but rather in the increased scientific understanding of facts (which were anticipated by Emile Durkheim, among others) and the amplification of the data reservoir which no longer fits a monolithic concept of religion. 
The Oxford English Dictionary defines secularisation as, 'the conversion of an ecclesiastical or religious institution or its property to secular possession and use' (taken from FOX 2005:292). Some researchers who focus on religion claim, therefore, that it is necessary to distinguish between the concepts of secularisation and secularism. While secularisation is related to the diminishing public importance of religion, secularism is the personal belief that 'morality should only take into account human and visible considerations' and that 'Secularists do not consider that moral codes should take into account, for instance, the existence of God, or of an afterlife' (Ibid.). In other words, secularisation can be viewed as in the public sphere and secularism as a privately held belief system (Ibid.).

These definitions of secularism and secularisation cannot be applied to the empirical material in this study in a straightforward way. Even though secularism may be referred to in the case of KDMS, since, as the respondent who lost his faith but continues to be active in KDMS proves, the members' moral values do not have to include faith in God, it cannot be defined as above, as a private belief system, because KDMS is engaged publicly.

The term 'secularisation' is also problematic, since KDMS's agenda perpetually refers to a religious interpretation of the world and legitimises its social vision through the 'sanctification' of certain cultural and societal items, e.g., sacred heterosexual marriage, the reliance on Biblical arguments in discussion about abortion, euthanasia, etc.

Hence, rather than talking about secularisation or secularism it would be wise to talk about the projection of religious content into political discourse, and rather than using imprudent phrases such as 'secularised Christianity', use of the term 'political Catholicism' is to be advised. Thus, the discussion here between exisiting theoretical approaches to the empirical material gathered for this study is more a contribution to the specific expression of political discourse legitimised by religion. Young Christian acitivists are not interesting because they are young Christian activists, but because, considering that they did not experience and do not remember the reality of the ideologies against which they define themselves, they are an indicator of a unique historical and cultural situation. Affording a bit of academic sarcasm at this point, it could be idsuggested that this study of young Christian Democrats in Slovakia be named Catholic ethics and the spirit of capitalism in Slovakia.

Though aware that Weberian and Durkheimian views on religion (in particular those concerning secularisation) are not perfectly compatible, the historical parallel with Weber's Protestants and the spirit of capitalism (1930) is very inspiring when reflecting upon politically active Slovak Catholics under the relatively new conditions of capitalism. It would be no surprise to any social scientist to claim that the principles of civil and market 
freedom are not the 'natural' status quo (as it may sometimes appear in the rhetoric of many Conservative Christian parties); however, they are a cultural construct on which one's political followers, benefactors and loyalists can be selected (see KURTZ 2001). If the symbols with which politicians operate are culturally defined, then logically it is not prescribed a priori that the political vision associated with Christianity must fall on the right-wing of the spectrum of political views.

Thus, Weber's message inspires the question: what is the essence of that 'ethos' of KDMS members which in their view closely aligns Christianity with a capitalist political and social vision and capitalism with democracy? Analyses of the data gathered leads to the suggestion that the collective remembering of a certain group of Slovak Catholics is that significant factor representing this 'ethos'.

Before presenting the final arguments of this statement, it would be useful to comment briefly on the history of political Catholicism in the Slovak context, on which basis the selective character of the historical memory that formulates KDMS's vision and political rhetoric might be identified.

In the 'Key findings' section above, the focus was on Slovak political Catholicism and the discourse of historical memory regarding the collective memories of Socialism and resistance to it as defined in Christian terms. The 'Key findings' section also presented arguments on the 'secular' aspect (in terms of political commitment) of the Christian(Catholic-) oriented political activism of youth who had not experienced this regime and who therefore did not remember it first hand.

Based on discussion with social science scholars concerning the historical context of political activism in Slovakia, the beginnings of political Catholicism cannot be viewed only in relation to Christian anti-Communism, nor in relation to the collective memory of a current group of young Christians which connects its political anti-left and anti-liberal (in social rather than economic terms) agenda with Christianity. The turning of Christian opinion closer to mundane issues in Slovakia does not result from Socialism or postSocialism. However, KDMS represents a special example of a modern Catholic-oriented political organisation, which is to a large extent based on historical experience with Socialism as a totalitarian regime. It is solidly based on the notion that Christianity in general and Catholicism in particular, which resisted such totalitarianism, guarantees adherence to the principles of free civil society (including adherence to the principles of a free capitalist market) and the prevention of a repeated spread of any form of totalitarianism. However, if the situation is evaluated from the perspective of a larger historical and geographic context, it can be seen that the political mobilisation of ideas 
interpreted as Christian has, in this geographical area, a longer history and far more faces to it than may seem the case at first sight.

The roots of secularised Christianity in Slovakia go back to the eighteenth, and particularly the nineteenth centuries, when Catholic, and later Protestant elites took part in defining the Slovak nation and supporting its self-determination by championing the middle class and refusing to allow feudalism to persist.

Neither nationally-oriented nor capitalist-oriented Christianity is self-evident, however, and its potential political and economic orientations only confirm the flexibility of Christian values as an argument for or source of a particular political or economic organisation of society. This flexibility is also proved by the story of Czech political Catholicism, although the historical memory of the respondents in this study does not stretch that far back. Although it is true that Slovak Catholics, from the founding of the first Czechoslovak Republic, at least until the end of World War II, inclined predominantly towards a nationally-oriented political version of Christianity, on the Czech side of the common state of Czechs and Slovaks significant voices of the politically involved clergy, with a leftist social and political orientation, appeared and promoted Christian solidarity (MACHÁLEK 2007:35).

In later historical developments, i.e., during World War II, Slovak Catholicism politically reflected the regime, described today as clerical fascism, which was later used by Socialist establishments as a means to discredit Slovak Catholics. However, the following forty years of one-party government, which persecuted and systematically marginalised Czechoslovak Christians (HLAVINKOVÁ 2007), caused believers to identify religious and political freedoms with capitalist systems in the USA and Western Europe which, incidentally, guaranteed those freedoms. As previously mentioned, in Slovakia it was mainly the Christian element that fought for the restoration of religion freedom ${ }^{15}$ and civil rights. It is not possible to assess historically the correlation between the success of the requirements imposed by these freedoms and the increasingly inevitable downfall of the Socialist bloc ruled by the Soviets. However, it must be stated that the transformation from the Socialist planned economy to a market economy became, at least in the discursus of the politically most active Christians, an integral part of the democratisation of society and vice versa. Nationalist tendencies among young Christian democrats, who became the most

15 And paradoxically many from these Christian elites strive vehemently to obstruct the registration and social acceptance of new churches and religious movements. 
influential political party referring to Christianity, were not reflected in their general rejection of the split of Czechoslovakia in 1993.

\section{Conclusions}

The thesis here suggests that the political success of Slovak post-revolution, political Catholicism results from this young historical memory of many Christians who selectively identified Christianity, oppressed by totalitarianism until recently, with the fight against totalitarianism and the fight for civil freedom. If Lowenthal claims that 'The past is everywhere around us. ... our present is based on our individual and collective awareness of the past.' (LOWENTHAL 2011:186), then political credit, acquired by political Catholicism after the revolution, is proof of this statement in Slovakia. Despite the fact that Christian rhetoric has recently appeared in activist movements with an extreme right orientation referring back to the Slovak State ${ }^{16}$ (remember that the respondents in this study resolutely reject such movements and potential cooperation with them), this research shows that KDMS youth selectively 'forget' the Catholic totalitarianism of the wartime Slovak State and most of them do not recall it when asked to name the eras of Slovak political activism. Considering the fact that some of the respondents 'remember' the Christian mission of St. Cyril and St. Methodius in the ninth Century and 'forget' Christian political activism in the century they were born, one's suspicion of selective historical memory on the part of KDMS youth is borne out.

It is no surprise to those dealing with collective memory issues that 'remembering' and 'forgetting' fall within the competence of both psychology (which deals with memory in psychological terms) and sociology, as 'memory' is also determined socially (SHOTTER 1997). The social aspect of memory (historical memory in particular) is mediated linguistically and especially through the linguistically-created illusion of particular experiences (historical in this case), and people become victims to it. (De MAN cited in SHOTTER 1997).

The linguistic creation of a particular version of reality is no doubt the most important strategy of a successful political rhetoric and a source of symbolic capital easily exchanged for political benefits.

The discourse equating Catholicism with anti-Communist resistance has weakened and this has been demonstrated by the rapid decrease in the number of KDMS members as 
well as by the increasing number of Catholics who support the Fascist Slovak State. As this process has occured, it seems that KDMS youth who are active in the organisation are (through the intergenerational transmission of historical memory and the authority of some political representatives rooted in the symbolic benefits gained from Christians' collective trauma during the Socialist regime - in particular by emphasising their own extremely stigmatized position in that period), the current holders of the Post-Socialistic 'discursive tradition'. This then becomes a frequent motive for their commitment as well as the framework from which their opinions on the current political scene are derived (e.g. fundamental opposition to the left-wing which is identified with communism).

Though the impact of one specific version of collective memory on the topic of this research is evident, there is still one peculiarity left as it seems that, just like the past, the present can be forgotten. This is proved by the anti-Communist fighter Ján Čarnogurský who is known also for his benevolent attitude towards the Catholic Fascist totalitarianism of World War II. However, this aspect of Čarnogurský's beliefs is avoided by young Christian Democrats, and this research where the attempt was made to detect potential conformity with the extreme rightist history of Slovak political Catholicism ${ }^{17}$, does not suggest that political correctness is the only reason for overlooking Čarnogurský's stance. Rather, it seems that the interpretive model of the past is so powerful that it overshadows the present itself.

\section{References}

CHISHOLME, L. and KOVACHEVA, S. (2002) Exploring the European youth mosaic. The social situation of young people in Europe, Strasbourg: Council of Europe.

DURKHEIM, É.(2002) Elementární formy náboženského života: systém totemismu v Austrálii, Praha: Oikoymenh.

FOX, J. (2005) 'Secularization' In. J. Hinnells (ed): The Routledge Companion to the Study of Religion, London: Routledge, pp. 291-305.

HLAVINKOVÁ, L. (2007) Socializmus jako sekularizovaná společnost: ",Být věříím" v době socialism - prìpadová studie, In. T. Bublík and H. Hoffmann (eds): Náboženství a politika, Pardubice: Pantheon, pp. 32-9. .

17 Except for several exemptions mentioned in key findings. 
MATEJ KARÁSEK - L'UBICA KOLLÁROVÁ

The Christian Democratic Youth of Slovakia: Christian Legacy, Post-Socialist Memory and the Spirit of Capitalism

KURTZ, D. (2001) Political anthropology: paradigms and power, Boulder, CO: Westview.

LOWENTHAL, D. (2011) The Past is a foreign country, Cambridge: Cambridge University Press.

MACHÁČEK, L. (1993) 'Združovací potenciál občanov SR', Sociológia 25(3): 217-26.

MACHÁLEK, V. (2007) 'Fenomén ,"politického katolicismu”: Československá strana lidová 1919-1948' In. T. Bublík and H. Hoffmann (eds): Náboženství a politika, Pardubice: Pantheon, pp. 32-39.

ROBERTS, G. (2001) The History and narrative reader, London: Routledge.

SHOTTER, J. (1997) 'The Social construction of remembering and forgetting'. In Middleton, D. and Edwards D. (eds): Collective remembering, New Delhi: Sage Publications.

ŠTEFANČíK, R. (2010) Politické mládežnícke organizácie na Slovensku, Bratislava: luventa.

WEBER, M (1930) The protestant ethic and the spirit of capitalism, London: Allen and Unwin. 